\title{
Antioxidant Capacity and Quinone Reductase Activity of Methanol Extracts and Fractions from Papaya Seed
}

\author{
Mi Hee $\mathrm{Yu}^{1^{\dagger}}$, Sung Gyu Lee ${ }^{1^{\dagger}}$, Hyo Gwon Im,2, In-Gyeong Chae ${ }^{1}$ Hyun-Jeong Kim ${ }^{3}$, Jinho Lee and \\ In-Seon Lee *
}

\author{
${ }^{1}$ Department of Food Science and Technology, Keimyung University, Daegu 704-701, Korea \\ ${ }^{2}$ Daegu Thechno Park Bio Industry Center, Daegu 704801, Korea \\ ${ }^{3}$ The Center for Traditional Microorganism Resources, Keimyung University, Daegu 704-701, Korea \\ ${ }^{4}$ Department of Chemistry, Keimyung University, Daegu 704-701, Korea
}

Received March 31, 2011 /Accepted April 24, 2011

\begin{abstract}
In this study, the antioxidant activity of methanol extracts and fractions from papaya seed were investigated in vitro. Total polyphenol contents of methanol extracts and fractions from papaya seed varied from 17.74 to $125.99 \mathrm{\mu g} / \mathrm{mg}$ and total flavonoid contents varied from 1.60 to $32.69 \mathrm{\mu g} / \mathrm{mg}$. Contents of polyphenol and flavonoid in ethyl acetate (EtOAc) fraction was found to be extremely high (compared with the other fractions examined). Radical-scavenging activities of methanol extracts and fractions were examined using a,a-diphenyl- $\beta$-picrylhydrazyl (DPPH) radicals, 2,2'-azino-bis (3-ethylbenzthiazoline-6-sulfonic acid) (ABTS) and hydrogen peroxide assay. As a result, ethyl acetate fraction of papaya seed showed the highest radical-scavenging activity in various antioxidant systems. The EtOAc fraction from papaya seed induced QR activity in concentrations of 12.5 to $50 \mu \mathrm{g} / \mathrm{ml}$ with a maximum of a 3.3-fold induction at $50 \mathrm{\mu g} / \mathrm{ml}$ of fraction. Therefore, the most effective QR inducer among these fractions can be said to reside in the EtOAc fraction, indicating that strong constituents responsible for QR induction potency in the papaya seed extract are largely contained in the EtOAc fraction.
\end{abstract}

Key words : Papaya, seed, antioxidant, quinone reductase, Hepa1c1c7 cells

\section{Introduction}

Reactive oxygen species (ROS) produced by ultraviolet light, ionizing radiation, chemical reaction, and metabolic processes have been associated with carcinogenesis, coronary heart disease, and many other health problems related to advancing age $[3,22,42]$. They include superoxide radical anion $\left({ }^{\bullet} \mathrm{O}_{2-}\right)$, hydroxyl radicals $\left({ }^{\bullet} \mathrm{OH}\right)$, singlet oxygen $\left({ }^{1} \mathrm{O}_{2}\right)$, and hydrogen peroxide $\left(\mathrm{H}_{2} \mathrm{O}_{2}\right)$. The damaging action of the hydroxyl radical is the strongest among free radicals [21]. Antioxidants can scavenge reactive oxygen species, which might have the potential to damage cell componets, such as DNA, proteins, and lipids. Oxidative damage might be involved in initiative events in cancer, and free radicals may help to induce the inhibition of apoptosis $[7,8,14,19]$.

Cancer chemoprevention is defined as the use of chemicals or dietary components to block, inhibit, or reverse the development of cancer in normal or preneoplastic tissue [46]. One mechanism responsible for the protective role of fruit

\footnotetext{
†These authors contributed equally to this work.

*Corresponding author

Tel : +82-53-580-5538, Fax : +82-53-580-5538

E-mail : inseon@kmu.ac.kr
}

and vegetable consumption is the induction of phase 2 xenobiotic metabolizing enzymes, which include quinone reductase (QR), glutathione $S$-transferase (GST), and UDP-glucuronosyltransferase (UGT) [37]. Phase 2 enzyme induction has emerged as an important strategy for cancer chemoprevention [35]. Based on their known pattern of enzyme induction, compounds that induce drug-metabolizing enzymes are classified into bifunctional inducers that elevate both phase 1 and 2 enzymes and monofunctional inducers that selectively elevate phase 2 enzymes. Monofunctional inducers of phase 2 enzymes are considered to have a greater potential as anticarcinogenic agents because they do not enhance the activation of carcinogens mediated by phase 1 enzymes such as cytochrome P-450 [31].

Papaya (Carica papaya L.) belongs to the family of Caricaceae grown in Australia, Hawaii, Philippines, SriLanka, South Africa, India, Bangladesh, Malaysia and a number of other countries in tropical America [28]. Papaya sarcocarps, seeds and peels have been used traditionally to treat various ailments in humans across the world. Papaya seed is found to be a rich source of biologically active isothiocyanate [25]. Particularly, the seeds are used as emmenagogue, thirst quenchers, carminatives or for bites and stings 
of poisonous insects [50]. Benzyl isothiocyanate (BITC), a chemopreventive phytochemical found in cruciferous vegetables [49] has also been shown to be present in different extracts of papaya seeds $[17,38,39]$. BITC exists in these plants as glucosinolate and is released by enzyme myrosinase-induced hydrolysis when the cellular/tissue integrity of the plants is disrupted by chopping during food preparation, seed crushing and other mechanical influences [41].

In this study, antioxidant activity of methanol extracts from papaya seed and its fractions were investigated in vitro. As an approach to the identification of new natural cancer chemopreventive agents, methanol extracts from papaya seed and its fractions were tested for their ability to induce QR in cultured Hepa1c1c7 murine hepatoma cells and Ah-receptor-defective mutant of Hepa1c1c7 (BP ${ }^{\mathrm{r}} \mathrm{c} 1$ cells).

\section{Materials and Methods}

\section{Chemicals}

All chemicals were obtained from Sigma Chemical (St. Louis, Mo., U.S.A) unless otherwise indicated. Cell culture reagents were purchased from Gibco BRL (Rockville, Md., U.S.A.) and fetal bovine serum (FBS) was from Hyclone (Logan, Utah, U.S.A.). Hepa1c1c7 cells were from the American Type Culture Collection (Rockville, Md., U.S.A.), and $\mathrm{BP}^{\mathrm{r}} \mathrm{c} 1$ cells were kindly provided by Dr. Jong-Sang Kim (Dept. of Animal Science and Biotechnology, Kyungpook Natl. Univ., Daegu, Republic of Korea).

\section{Preparation of samples}

Papaya sarcocarp, seed and peel were extracted with methanol, and the methanol extract of papaya seed was then partitioned with n-hexane, chloroform, ethyl acetate, n-butanol, and water. The extract and solvent fractions were concentrated under reduced pressure and lyophilized. The yields $(w / w)$ obtained for the methanol extract and its $n$-hexane, chloroform, ethylacetatd, n-butanol and water fractions were about $1.6 \%, 2.8 \%, 1.4 \%, 0.5 \%, 8.0 \%$ and $61.1 \%$, respectively.

Determination of total polyphenols and total
flavonoids

The concentrations of total polyphenols and total flavonoids were measured by the Folin-Denis method [11] and the method described by Nivea Moreno and other [27], respectively. Total polyphenols and total flavonoids contents were expressed as tannic acid and quercetin molar equiv- alents, respectively.

\section{Scavenging of $\quad a-a-d i p h e n y l-\beta$-picrylhydrazyl $\quad$ (DPPH) radical}

The free radical scavenging activity of sample was measured by the a-a-diphenyl- $\beta$-picrylhydrazyl (DPPH). This assay was carried out as described by Blois [2] with some modifications. In its radical form, $\mathrm{DPPH}^{\bullet}$ absorbs at $517 \mathrm{~nm}$ but upon reduction by antioxidant or a radical species its absorption decreases. Briefly, $0.15 \mathrm{mM}$ solution of $\mathrm{DPPH}^{\circ}$ in ethanol was prepared and $200 \mu \mathrm{l}$ of this solution was added to $800 \mu \mathrm{l}$ of sample solution in ethanol at different concentrations. After $30 \mathrm{~min}$, the absorbance was measured at $517 \mathrm{~nm}$. Lower absorbance of the reaction mixture indicates higher free radical scavenging activity [13]. The free radical scavenging activity of each solution was then calculated as percent inhibition according to the following equation:

$\mathrm{DPPH}^{\bullet}$ scavenging effect $(\%)=\left(\mathrm{A}_{\text {Control }}-\mathrm{A}_{\text {Sample }} / \mathrm{A}_{\text {Control }}\right) \times 100$

\section{Scavenging of ABTS radical}

The spectrophotometric analysis of $\mathrm{ABTS}+{ }^{\bullet}$ radical scavenging activity was determined according to the method of Re et al. [33]. ABTS ${ }^{-}$cation radical was produced by the reaction between $7 \mathrm{mM}$ ABTS in $\mathrm{H}_{2} \mathrm{O}$ and $2.45 \mathrm{mM}$ potassium persulfate, stored in the dark at room temperature for $24 \mathrm{hr}$. Before usage, the ABTS+ ${ }^{*}$ solution was diluted to get an absorbance of $0.70 \pm 0.02$ at $732 \mathrm{~nm}$ with phosphate buffer (0.1 M, pH 7.4). Then, $990 \mu \mathrm{l} \mathrm{of} \mathrm{ABTS+}{ }^{\bullet}$ solution was added $10 \mu \mathrm{l}$ of sample. After $1 \mathrm{~min}$, the percentage inhibition at $732 \mathrm{~nm}$ was calculated for each concentration relative to a blank absorbance.

\section{Scavenging of hydrogen peroxide radical}

The scavenging of hydrogen peroxide radical were measured by method described by Muller others [24]. Sample 20 $\mu \mathrm{l}$ and $1 \mathrm{mM} \mathrm{H}_{2} \mathrm{O}_{2}$ in phosphate buffered saline (PBS) 100 $\mu \mathrm{l}$ incubated for $5 \mathrm{~min}$ at room temperature. And then 1.25 $\mathrm{mM}$ ABTS $30 \mu \mathrm{l}$ and $1 \mathrm{unit} / \mathrm{ml}$ peroxdase $30 \mu \mathrm{l}$ were added. After 10 min at $37^{\circ} \mathrm{C}$, amount of $\mathrm{H}_{2} \mathrm{O}_{2}$ was determined by measuring absorption at $532 \mathrm{~nm}$.

\section{Determination of $Q R$ activity in cell culture}

We first determined the dose-dependent characterisitics of the cytotoxic effects of the extract by means of a 3-(4,5-dimethylthiazolyl)-2,5-diphenyltetrazolium bromide (MTT) assay. Hepa1c1c7 and $\mathrm{BP}^{\mathrm{r}} \mathrm{cl}$ cells were cultured as described previously [31]. In brief, cells were grown in 
96-well plates at a density of $1 \times 10^{4} / \mathrm{ml}$ in $200 \mu \mathrm{ll}$ of a-MEM containing $100 \mathrm{unit} / \mathrm{ml}$ of penicillin G sodium salt, $100 \mu$ $\mathrm{g} / \mathrm{ml}$ of streptomycin sulfate, and $250 \mathrm{ng} / \mathrm{ml}$ of amphotericin B supplemented with $10 \% \mathrm{FBS}$ at $37^{\circ} \mathrm{C}$ in a $5 \% \mathrm{CO}_{2}$ atmosphere. After a preincubation period of $24 \mathrm{hr}$, the medium was changed, lyophilized samples dissolved in DMSO were added, and the plates were incubated for an additional $48 \mathrm{hr}$. QR activity was determined by measuring the $\mathrm{NAD}(\mathrm{P}) \mathrm{H}$-dependent menadiol-mediated reduction of MTT to blue formazan. Cellular protein was determined using a bicinchonic acid (BCA) protein assay kit (Sigma Chemical) in an identical set of test plates. The induction of $\mathrm{QR}$ activity was calculated from the ratio of specific enzyme activities of sample-treated cells in comparison with a nontreated control.

\section{Results and discussion}

\section{Determination of total polyphenols and flavonoids}

The content of total polyphenols and flavonoids contained in the methanol extracts from sarcocarp, seed and peel of papaya were measured using tannic acid and quercetin respectively, as standard compounds (Table 1). Contents of total polyphenols in methanol extract of sarcocarp, seed and peel were 4.67, 25.47, $7.99 \mu \mathrm{g} / \mathrm{mg}$ and total flavonoids contents were 1.10, 3.92, $2.62 \mu \mathrm{g} / \mathrm{mg}$, respectively. The methanol extract of papaya seed contained higher levels of total polyphenols and flavonoids than papaya sarcocarp and peel. Therefore, we investigated antioxidant capacity and quinone reductase activity using methanol extracts of papaya seed and its fractions. Total polyphenols and flavonoids contents in fractions of papaya seed varied from 17.74 to $125.99 \mathrm{\mu g} /$ $\mathrm{mg}$ and from 1.6 to $32.69 \mathrm{\mu g} / \mathrm{mg}$, respectively (Table 2). Phenolic compounds are secondary metabolites which are widely distributed in the plant kingdom, they have diverse structures and molecular weights, and their major composition is flavonoids and tannin. The contents of total phenolics
Table 2. Contents of total polyphenols and flavonoids in methanol extracts and fractions of papaya seed

\begin{tabular}{lcc}
\hline Sample & $\begin{array}{c}\text { Total polyphenols }{ }^{1)} \\
(\mu \mathrm{g} / \mathrm{mg})\end{array}$ & $\begin{array}{c}\text { Total flavonoids }{ }^{2} \\
(\mu \mathrm{g} / \mathrm{mg})\end{array}$ \\
\hline MeOH extract & $25.47 \pm 7.24^{33}$ & $3.92 \pm 1.23$ \\
Hexane fraction & $17.74 \pm 4.33$ & $3.17 \pm 0.71$ \\
$\mathrm{CHCl}_{3}$ fraction & $31.9 \pm 3.51$ & $5.18 \pm 0.82$ \\
$\mathrm{EtOAc}^{3}$ fraction & $125.99 \pm 12.97$ & $32.69 \pm 0.58$ \\
$\mathrm{BuOH}$ fraction & $69.08 \pm 13.47$ & $4.93 \pm 0.68$ \\
Water fraction & $19.15 \pm 4.46$ & $1.6 \pm 0.18$
\end{tabular}

${ }^{11}$ Micrograms of total polyphenol content/mg of plants based on tannic acid as standard.

${ }^{2)}$ Micrograms of total flavonoid content/mg of plants based on quercetin as standard.

${ }^{3)}$ Each value is mean $\pm \mathrm{SD}(\mathrm{n} \geq 3)$.

were relatively high and comparable to other vegetables and medicinal plants, which have shown pharmacological potential such as antioxidant and chemopreventive effect $[16,20]$. Since they contain phenolic hydroxyl $(\mathrm{OH})$ groups, they bind readily to proteins and macromolecules, and they have antioxidation, anticancer, and various other physiological activities [34]. Flavonoids and other polyphenols can modulate phase II metabolism, in part via an impact on signal transduction pathways that affect the antioxidant-response element $[12,40]$.

Antioxidant capacity of methanol extracts of papaya seed and its fractions

We examined the antioxidant activities of the methanol extract and its fractions of papaya seed by measuring their abilities to transfer hydrogen to the stable free radicals $\mathrm{DPPH}, \mathrm{ABTS}$ and $\mathrm{H}_{2} \mathrm{O}_{2}$. In these experiments, $\mathrm{BHA}$, ascorbic acid and trolox were used as control compounds, respectively. The radical-scavenging activities, as indicted by their $\mathrm{RC}_{50}$ values, differed between the methanol extract and the various solvent fractions (Table 3), and the scavenging activity increased in a concentration-dependent manner for all radical species (data not shown). The results indicate that

Table 1. Contents of total polyphenols and flavonoids in methanol extracts from sarcocarp, seed and peel of papaya

\begin{tabular}{cccc}
\hline \multirow{2}{*}{ Plant } & Part used & Total polyphenols ${ }^{1)}$ & $\begin{array}{c}\text { Total flavonoids }^{2} \\
(\mu \mathrm{g} / \mathrm{mg})\end{array}$ \\
\hline \multirow{3}{*}{ Papaya } & sarcocarp & $4.67 \pm 0.14^{3)}$ & $1.10 \pm 0.25$ \\
& seed & $25.47 \pm 7.24$ & $3.92 \pm 1.23$ \\
& peel & $7.99 \pm 0.55$ & $2.62 \pm 0.66$ \\
\hline
\end{tabular}

\footnotetext{
${ }^{1)}$ Micrograms of total polyphenol content/mg of plants based on tannic acid as standard.
}

${ }^{2)}$ Micrograms of total flavonoid content/mg of plants based on quercetin as standard.

${ }^{3)}$ Each value is mean \pm SD $(n \geq 3)$. 
Table 3. Scavenging effects of methanol extracts and fractions of papaya seed on a, a-diphenly- $\beta$-picrylhydrazyl radicals (DPPH $\cdot$ ), ABTS radicals and hydrogen peroxide $\left(\mathrm{H}_{2} \mathrm{O}_{2}\right)$

\begin{tabular}{clccc}
\hline \multirow{2}{*}{ Sample } & \multirow{2}{*}{ Fraction } & \multicolumn{3}{c}{$\mathrm{RC}_{50}{ }^{1)}(\mu \mathrm{g} / \mathrm{ml})$} \\
\cline { 3 - 5 } & MeOH extract & $66.28 \pm 3.65$ & $\mathrm{ABTS}$ & $\mathrm{H}_{2} \mathrm{O}_{2}$ \\
\hline \multirow{3}{*}{ Papaya } & Hexane fraction & $82.44 \pm 2.04$ & $116.52 \pm 4.86$ & $121.69 \pm 9.33$ \\
\multirow{2}{*}{ seed } & $\mathrm{CHCl}_{3}$ fraction & $55.34 \pm 5.53$ & $275.71 \pm 6.38$ & $241.29 \pm 12.97$ \\
& EtOAc fraction & $10.95 \pm 1.02$ & $109.29 \pm 3.58$ & $193.65 \pm 9.82$ \\
& BuOH fraction & $21.82 \pm 1.47$ & $19.75 \pm 0.47$ & $41.17 \pm 2.22$ \\
& Water fraction & $103.84 \pm 2.34$ & $53.94 \pm 7.60$ & $49.13 \pm 4.65$ \\
& BHA & $3.11 \pm 1.15$ & $249.67 \pm 11.23$ & $167.86 \pm 8.69$ \\
& Ascorbic acid & $2.09 \pm 1.03$ & - & - \\
& Trolox & - & $24.57 \pm 2.35 \mu \mathrm{M}$ & $33.96 \pm 3.03 \mu \mathrm{M}$ \\
\hline
\end{tabular}

${ }^{1)}$ Concentration required for $50 \%$ reduction of free radicals at $30 \mathrm{~min}$ after starting the reaction.

${ }^{2)}$ Each value is mean \pm SD $(n \geq 3)$.

among the fractions of papaya seed, the EtOAc fraction was the most potent scavenger of DPPH free radicals $\left(\mathrm{RC}_{50}=10.95 \pm 1.02 \mu \mathrm{g} / \mathrm{ml}\right)$. Furthermore, the EtOAc fracion was the strongest antioxidant amongst the various fractions of papaya seed in the ABTS and $\mathrm{H}_{2} \mathrm{O}_{2}$ assay system, with $\mathrm{RC}_{50}$ of $19.75 \pm 0.47 \mu \mathrm{g} / \mathrm{ml}$ and $41.17 \pm 2.22 \mu \mathrm{g} / \mathrm{ml}$, respectively. The EtOAc fraction exhibited lower $\mathrm{RC}_{50}$ values than trolox, indicating better radical-scavenging activity, whereas the methanol extract and the hexane, chloroform and water fractions had higher $\mathrm{RC}_{50}$ values and, thus, relatively low activity.

According to our results, the methanol extract of papaya seed contained higher levels of total polyphenols and flavonoids than papaya sarcocarp and peel. Contents of polyphenol and flavonoid in ethyl acetate fraction of papaya seed extract was found to be extremely high compared with the other fractions examined. In addition, the fraction showed the highest radical-scavenging activity in various antioxidant system. The result of DPPH scavenging activity assay in this study indicates that the EtOAc fraction was potently active. This suggests that the fraction contain compounds that are capable of donating hydrogen to a free radical in order to remove odd electron which is responsible for radical's reactivity. The ability of this plant extract to scavenge DPPH could also reflect its ability to inhibit the formation of ABTS+. The scavenging activity of ABTS+ radical by the plant extract was found to be appreciable; this implies that the plant extract may be useful for treating radical related pathological damage [45]. $\mathrm{H}_{2} \mathrm{O}_{2}$ is formed in vivo by a variety of enzymes, including superoxide dismutase. $\mathrm{H}_{2} \mathrm{O}_{2}$ is most generally considered as a powerful oxidizing agent. There is increasing evidence that $\mathrm{H}_{2} \mathrm{O}_{2}$, either directly or indirectly via its reduction product $\mathrm{OH}^{-}$, acts as a messenger molecule in the synthesis and activation of inflammatory mediators [1]. Hydrogen peroxide itself is not very reactive; however, it can sometimes be toxic to cells because it may give rise to hydroxyl radical within the cells. $\mathrm{H}_{2} \mathrm{O}_{2}$ to cells in culture can lead to transition metal ion-dependent $\mathrm{OH}$ radicals mediating oxidative DNA damage. Thus, removing hydrogen peroxide is very important for protection of pharmaceuticals and food systems [4].

Induction of quinone reductase in Hepa1c1c7 cells and BPrc1 cells by methanol extracts of papaya seed and its fractions

QR is primarily a cytosolic flavoprotein that catalyzes the reduction of a wide variety of quinones and quinoneimines. QR protects cells against the toxicity of xenobiotics by promoting the obligatory 2-electron reduction of quinones to hydroquinones, which are then susceptible to glucuronidation and excretion [23]. Therefore, an assay for QR induction in vitro represents a simple method for screening compounds for potential anticarcinogenic properties. Assessing QR activity as a biomarker of phase II metabolism has commonly been employed to screen the potential chemopreventive activity of phytochemicals [32]. Most flavonoids show antioxidative activity and, therefore, are likely to prevent carcinogenesis by inducing detoxifying enzymes such as quinone reductase and glutathione reductase $[30,43,51]$. The induction of QR in cultured Hepa1c1c7 cells has been used to assess the potential of compounds from edible sources such as sulforaphane from broccoli [52] and resveratrol from grapes [15]. Also, one of the most intensively studied ITCs with regard to cancer chemo- 
Table 4. Induction of quinone reductase $(\mathrm{QR})$ and cytotoxic effects mediated by a methanol extract of papaya seed and its fractions in Hepa1c1c7 cells

\begin{tabular}{lccc}
\hline Sample & $\mathrm{CD}^{\mathrm{a}}(\mathrm{mg} / \mathrm{ml})$ & $\mathrm{IC}_{50}^{\mathrm{b}}(\mathrm{mg} / \mathrm{ml})$ & $\mathrm{Cl}^{\mathrm{c}}$ \\
\hline MeOH extract & 0.160 & 0.226 & 1.413 \\
Hexane fraction & 0.027 & 0.224 & 8.296 \\
$\mathrm{CHCl}_{3}$ fraction & 0.086 & 0.133 & 1.547 \\
EtOAc fraction & 0.028 & 0.180 & 6.429 \\
BuOH fraction & 0.031 & 0.104 & 3.355 \\
Water fraction & 0.079 & 0.463 & 5.861 \\
\hline
\end{tabular}

${ }^{a}$ Mean value of the concentration required to double the specific activity of QR.

${ }^{b}$ Mean value of the half-maximal inhibitory concentration of cell viability.

${ }^{\mathrm{c}}$ The ratio between $\mathrm{IC}_{50}$ and $\mathrm{CD}$.

prevention is benzyl isothiocyanate (BITC), a product of enzymatic hydrolysis of glucotropaeolin. BITC is contained in high amounts in papaya (Carica papaya), garden cress (Lepidium sativum) and common Brassica vegetables $[10,29,39,44]$ and some studies show the potential of this compound as a chemopreventive agent in man $[5,6,47-49,53]$.

Both epidemiological studies and in vitro and in vivo experiments have found that various compounds from many plant sources, mostly fruits and vegetables, offer protection against various types of cancer. Among many vegetables, cruciferous vegetable belong to the species Brassica (for example, broccoli, cabbage, cauliflower, kale) have been known as important dietary contributors to cancer prevention. In general, broccoli and brussels sprouts have been known as the most potent sources. Cruciferous vegetables are the best dietary source of health promoting glucosinolate conversion products such as sulforaphane [26,35] and their protective effect against cancer has been attributed to the induction of phase 2 enzyme such as QR [9].

To obtain further information relative to the characteristics of the active compound(s) responsible for $\mathrm{QR}$ induction potency, the methanol extract was fractionated using a series of solvents of increasing polarity. CDs (the concentration required to double the specific activity of $\mathrm{QR}), \mathrm{IC}_{50} \mathrm{~S}$ and $\mathrm{CIs}$ (the ratio between $\mathrm{IC}_{50}$ and $\mathrm{CD}$ ) obtained for methanol extracts of papaya seed and various solvent fractions are shown in Table 4. The CDs obtained for the hexane and EtOAc fractions were about 1.2 to 5.9 -fold lower than those obtained for the other fractions, and CDs for all of the fractions were lower than that obtained for the methanol extract, implying that these fractions had higher induction activities for QR than the methanol extract. The $\mathrm{IC}_{50} \mathrm{~s}$, an indication of cytotoxicity, obtained for the fractions, except the water fraction, were about $0.1-0.2 \mathrm{mg} / \mathrm{ml}$, whereas the $\mathrm{IC}_{50}$ ob- tained for the water fraction was much higher than that of the others. Although the CI obtained for the hexane fraction was higher than those obtained for the others, this result was due to its lower cytotoxicity in Hepalc1c7 cells. The EtOAc fraction from papaya seed induced QR activity in the concentration 12.5 to $50 \mathrm{\mu g} / \mathrm{ml}$ with a maximum of a 3.3-fold induction at $50 \mu \mathrm{g} / \mathrm{ml}$ of fraction (Fig. 1). But the hexane fraction induced QR activity with a maximal 2.0-fold increase at a concentration of $25 \mu \mathrm{g} / \mathrm{ml}$.

To determine whether the extract is a monofunctional inducer of $\mathrm{QR}$, its ability to increase $\mathrm{QR}$ activity in the mutant cell line of Hepa1c1c7, $\mathrm{BP}^{\mathrm{r}} \mathrm{c} 1$, was examined. As shown in Figure 2, the methanol extract of papaya seed and its fractions did not induce QR activity in the mutant $\mathrm{BP}^{\mathrm{r}} \mathrm{c} 1$ cells, and this indicates that the mutant BPrc1 cell line used in this experiment responded in the predicted manner to a

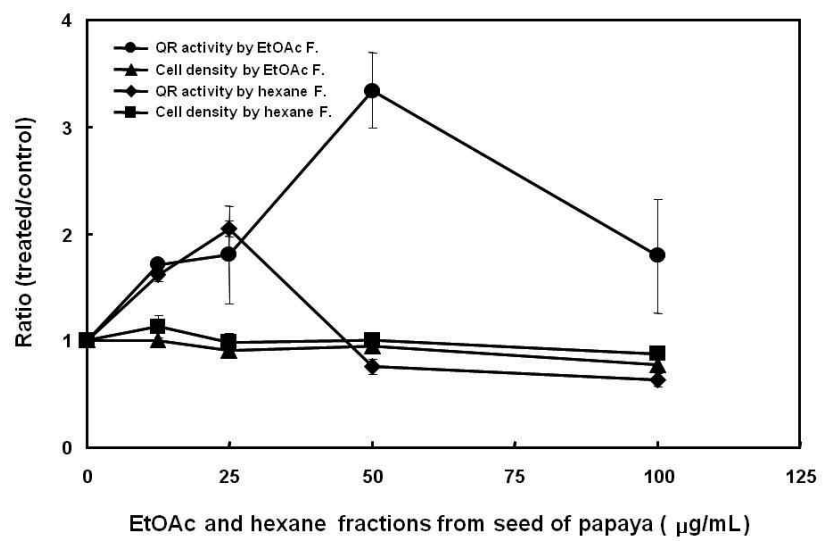

Fig. 1. Induction of quinone reductase $(\mathrm{QR})$ in Hepa1c1c7 cells by EtOAc and hexane fractions of papaya seed. Cells were treated with the fraction in a concentration range of 0 to $100 \mathrm{\mu g} / \mathrm{ml}$ for $48 \mathrm{hr}$. Each value represents the mean \pm standard deviation of 3 independent experiments and is expressed relative to a vehicle control. 


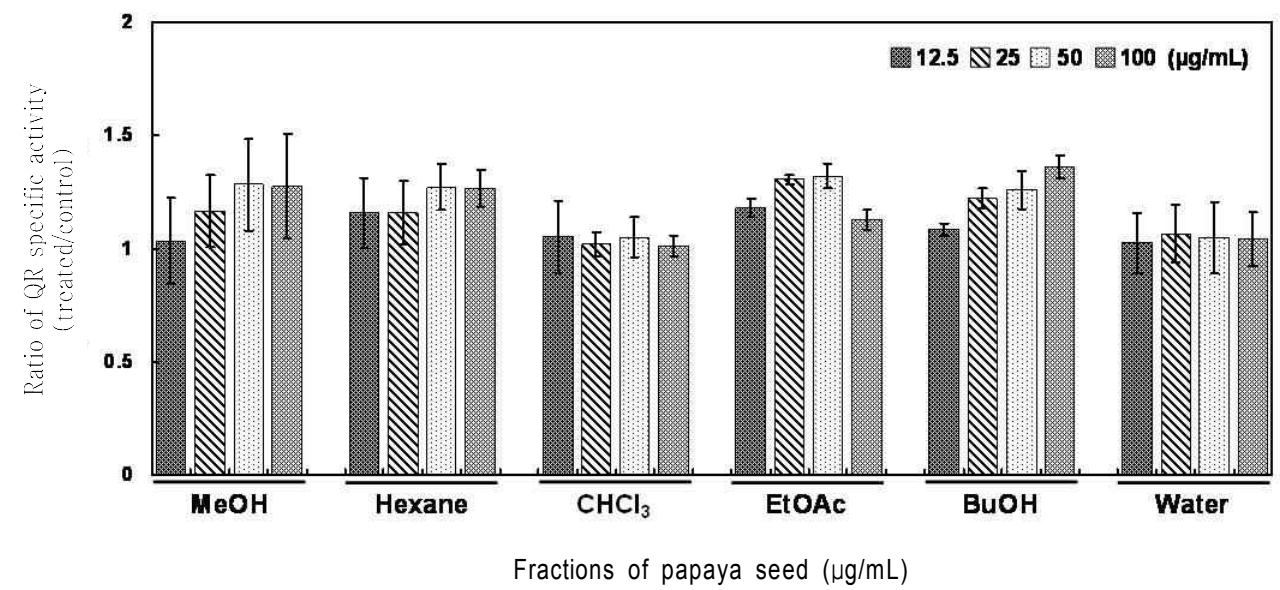

Fig 2. Quinone reductase (QR) activity of Ah-receptor-defective mutant of Hepa1c1c7 cells (BPrc1) treated with methanol extracts and fractions of papaya seed. Cells were treated with the fraction in a concentration range of 12.5 to $100 \mu \mathrm{g} / \mathrm{ml} \mathrm{for} 48 \mathrm{hr}$. Each value represents the mean \pm standard deviation of 3 independent experiments and is expressed relative to a vehicle control.

well-characterized bifunctional inducer. Mutant cell line of Hepa1c1c7, BP ${ }^{\mathrm{r}} \mathrm{c}$ cells lacking arylhydrocarbon receptor nuclear translocator (ARNT), which are typical murine hepatoma cell lines highly responsive to phase 2 enzyme inducers and thereby widely used for screening phase 2 enzyme inducers [18]. The methanol extract of papaya seed and its fractions did not induce $\mathrm{QR}$ activity in the mutant $\mathrm{BP}^{\mathrm{r}} \mathrm{c} 1$ cells (Fig. 2).

Overall, the data indicate that papaya seed has a positive impact on the phase II enzymes QR, suggesting that they may enhance detoxification of carcinogens/toxins and their removal from the body. Various compounds, natural and synthetic, are capable of elevating phase II enzyme activity and are classified as monofunctional (phase II) inducers [31]. Bifunctional inducers have the capacity to increase both phase I and phase II enzymes. These data are consistent with the finding of Talalay et al. [36] that the flavonoids, which occur abundantly in many common edible plants, are typical bifunctional inducers.

Therefore, the most effective QR inducer among these fractions is resided in the EtOAc fraction, indicating that strong constituents responsible for $\mathrm{QR}$ induction potency in the papaya seed extract are largely contained in the EtOAc fraction.

\section{Acknowledgements}

This work was supported by the Korea Science and Engineering Foundation (KOSEF) grant funded by the Korea government (MEST) (No. 353-2009-1-F00018), and the Grant of the Korean Ministry of Education, Science and Technology (The Regional Core Research Program/Anti-aging and Well-being Research Center).

\section{References}

1. Ak, T. and İ. Gülcin. 2008. Antioxidant and radical scavenging properties of curcumin. Chem Biol. Interact. 174, 27-37.

2. Blois, M. S. 1958. Antioxidant determinations by the use of a stable free radical. Nature 181, 1199-1200.

3. Cadenas, E. and K. J. A. Davies. 2000. Mitochondrial free radical generation, oxidative stress, and aging. Free Radic. Biol. Med 29, 222-230.

4. Chai, P. C., L. H. Long, and B. Halliwell. 2003. Contribution of hydrogen peroxide to the cytotoxicity of green tea and red wines. Biochem Biophys. Res. Commun. 304, 650-654.

5. Chung, F. L. 1992. Chemoprevention of lung carcinogenesis by aromatic isothiocyanates. pp. 227-245, In Wattenberg, L. W., M. Lipkin, C. W. Boone, and G. J. Kelloff (eds.), Cancer Chemoprevention. CRC Press, Boca Raton, FL.

6. Chung, F. L., M. Wang, and S. S. Hecht. 1985. Effects of dietary indoles and isothiocyanates on N-nitrosodimethylamine and 4-(methylnitrosamino)-1-(3-pyridyl)-butanone hydroxylation and DNA methylation in rat liver. Carcinogenesis 6, 539-543.

7. Chung, H. S., L. C. Chang, S. K. Lee, L. A. Shamon, R. B. van Breemen, R. G. Mehta, N. R. Farnsworth, J. M. Pezzuto, and A. D. Kinghorn. 1999. Flavonoid constituents of Chorizanthe diffusa with potential cancer chemopreventive activity. J. Agric. Food Chem 47, 36-41.

8. Doll, R. 1990. An overview of the epidemiological evidence linking diet and cancer. Proc. Nutr. Soc. 49, 119-131.

9. Fahey, J. W. and P. Talalay. 1999. Antioxidant functions of sulforaphane: a potent inducer of phase II detoxication 
enzymes. Food Chem Toxicol. 37, 973-979.

10. Fenwick, G. R., R. K. Heany, and L. W. Mullin. 1983. Glucosinolates and their breakdown products in foods and food plants. Crit. Rev. Food Sci. Nutr. 18, 123-201.

11. Folin, O. and W. Denis. 1912. On phosphotungstic-phosphomolybdic compounds as color reagents. J. Biol. Chem 12, 239-249.

12. Ford, E. S. and A. Sowell. 1999. Serum R-tocopherol status in the United States population: Findings from the Third National Health and Nutrition Examination Survey. Am J. Epidemiol. 150, 290-300.

13. Gülcin, İ., E. Bursal, M. H. Sehitoğlu, M. Bilsel, and A. C. Gőren. 2010. Polyphenol contents and antioxidant activity of lyophilized aqueous extract of propolis from Erzurum, Turkey. Food Chem Toxicol. 48, 2227-2238.

14. Hertog, M. G., P. M. Sweetnam, A. M. Fehily, P. C. Elwood, and D. Kromhout. 1997. Potentially Anticarcinogenic Secondary Metabolites from Fruit and Vegetables. pp. 313-329, Clarendon Press, Oxford.

15. Jang, M., L. Cai, G. O. Udeani, K. V. Slowing, C. F. Thomas, C. W. Beecher, H. H. Fong, N. R. Farnsworth, A. D. Kinghorn, R. G. Mehta, R. C. Moon, and J. M. Pezzuto. 1997. Cancer chemopreventive activity of resveratrol, a natural product derived from grapes. Science 10, 218-220.

16. Johns, T., R. L. Mahunnah, P. Sanaya, L. Chaprnan, and T. Ticktin. 1999. Saponins and phenolic content in plant dietary additives of a traditional subsistence community, the Batemi of Ngorongoro District, Tanzania. J. Ethnopharmacol. 66, 1-10.

17. Kermanshai, R., B. E. McCarry, J. Rosenfeld, P. S. Summers, E. A. Weretilnyk, and G. J. Sorger. 2001. Benzyl isothiocyanate is the chief or sole anthelmintic in papaya seed extracts. Phytochemistry 57, 427-435.

18. Kim, B. R., R. Hu, Y. S. Keum, V. Hebbar, G. Shen, S. S. Nair, and A. N. Kong. 2003. Effects of gluathione on antioxidant responese element-mediated gene expression and apoptosis elicited by sulforaphane. Cancer Res. 63, 7520-7525.

19. Kuo, S. M. 1996. Antiproliferative potency of structurally distinct dietary flavonoids on human colon cancer cells. Cancer Lett. 110, 41-48.

20. Lee, S. O., H. J. Lee, M. H. Yu, H. G. Im, and I. S. Lee. 2005. Total polyphenol contents and antioxidant activities of methanol extracts from edible vegetables produced in Ullung island. Korean J. Food Sci. Technol. 37, 233-240.

21. Liu, F. 2000. Antioxidative and free radical scavenging activities of selected medicinal herbs. Life Sci. 66, 725-735.

22. Marnett, L. J. 2000. Oxyradicals and DNA damage. Carcinogenesis 21, 361-370.

23. Miranda, C. L., G. L. Aponso, J. F. Stevens, M. L. Deinzer, and D. R. Buhler. 2000. Prenylated chalcones and flavanones as inducers of quinone reductase in mouse Hepa 1c1c7 cells. Cancer Lett. 28, 21-29.

24. Muller, H. E. 1985. Detection of hydrogen peroxide produced by microorganism on ABTS-peroxidase medium. Zentralbl. Bakteriol. Mikrobiol. Hygiene 259, 151-154.

25. Nakamura, Y., M. Toshimoto, Y. Murata, Y. Shimoishi, Y. Asai, E. Y. Park, and K. Sato. 2007. Papaya seed represents a rich source of biologically active isothiocyanate. J. Agric. Food Chem 55, 4407-4413.

26. Nestle, M. 1997. Broccoli sprouts as inducers of carcinogen-detoxifying enzyme systems: clinical, dietary, and policy implications. Proc. Natl. Acad Sci. USA 14, 11149-11151.

27. Nieva Moreno, M. I., M. I. Isla, A. R. Sampietro, and M. A. Vattuone. 2000. Comparison of the free radical-scavenging activity of propolis from several regions of Argentina. J. Ethnopharmacol. 71, 109-114.

28. OECD (Environment Directorate Joint Meeting of the Chemicals Committee and the Working Party on Chemicals, Pesticides and Biotechnology), 2005. Consensus Document on the Biology of Papaya (Carica papaya) Series on Harmonisation of Regulatory Oversight in Ciotechnology No 33.

29. Pintao, A. M., M. S. Pais, H. Coley, L. R. Kelland, and J. R. Judson. 1995. In vitro and in vivo antitumor activity of benzyl isothiocyanate a natural product of Tropeolum majus. Planta Med 61, 233-236.

30. Primiano, T., T. R. Sutter, and T. W. Kensler. 1997. Antioxidant inducible gene. Adv. Pharmacol. 38, 293-328.

31. Prochaska, H. J. and A. B. Santamaria. 1988. Direct measurement of $\mathrm{NAD}(\mathrm{P}) \mathrm{H}$ :quinone reductase from cells cultured in microtiter well: a screening assay for anticarcinogenic enzymes inducers. Anal. Biochem 169, 328-336.

32. Prochaska, H. J. and P. Talalay. 1988. Regulatory mechanism of monofunctional and bifunctional anticarcinogenic enzymes in murine liver. Cancer Res. 48, 4682-4776.

33. Re, R., N. Pellegrini, A. Proteggente, A. Pannala, M. Yang, and C. Rice-Evans. 1999. Antioxidant activity applying an improved ABTS radical cation decolorization assay. Free Radic. Biol. Med 26, 1231-1237.

34. Rice-Evans, C. A., N. J. Miller, and G. Panganga. 1997. Antioxidant properties of phenolic compounds. Trends Plant Sci. 2, 152-159.

35. Talalay, P. 2000. Chemoprotection against cancer by induction of phase 2 enzymes. Biofactors 12, 5-11.

36. Talalay, P., J. W. Fahey, W. D. Holtzclaw, T. Prestera, and Y. Zhang. 1995. Chemoprotection against cancer by phase 2 enzyme induction. Toxicol. Lett. 82-83, 173-179.

37. Talalay, P. 1989. Mechanisms of induction of enzymes that protect against chemical carcinogenesis. Adv. Enzyme Regul. 28, 237-250.

38. Tang, C. S. 1971. Benzyl isothiocyanate in papaya fruit. Phytochemistry 12, 117-121.

39. Tang, C. S., M. M. Syed, and R. A. Hamilton. 1972. Benzyl isothiocyanate in the Caricaceae. Phytochemistry 11, 2531-2535.

40. Tanigawa, S., M. Fujii, and D. X. Hou. 2007. Action of Nrf2 and Keap1 in ARE-mediated NQO1 expression by quercetin. Free Radic. Biol. Med 42, 1690-1703.

41. Tookey, H. L., C. H. Van Etten, and M. E. Daxenbichler. 1980. Glucosinolates. pp. 103-142, In Liener, I. E. (ed.), Toxic Constituents of Plant Stuffs.

42. Uchida, K. 2000. Role of reactive aldehyde in cardiovascular 
diseases. Free Radic. Biol. Med 28, 1685-1696.

43. Uda, Y., K. R. Price, G. Wklliamson, and M. J. Rhodes. 1997. Induction of the anticarcinogenic marker enzyme, quinone reductase, in murine hepatoma cells in vitro by flavonoids. Cancer Lett. 120, 213-216.

44. VanEtten, C., M. E. Daxenbichler, P. H. Williams, and W. F. Klodek. 1976. Glucosinolates and derived products in cruciferous vegetables. Analysis of the edible parts of 22 varieties of cabbage. J. Agric. Food Chem 24, 452-455.

45. Wang, M., J. Li, M. Rangarajan, Y. Shao, E. J. La Voie, T. Huang, and C. Ho. 1998. Antioxidative phenolic compounds from sage (Salvia officinalis). J. Agric. Food Chem 46, 4869-4873.

46. Wattenberg, L. W. 1985. Chemoprevention of cancer. Cancer Res. 45, 1-8.

47. Wattenberg, L. W. 1977. Inhibition of carcinogenic effects of polycyclic hydrocarbons by benzyl isothiocyanate and related compounds. J. Natl. Cancer Inst. 58, 395-398.

48. Wattenberg, L. W. 1981. Inhibition of carcinogen induced neoplasia by sodium cyanate, tert-butyl isocyanate and benzyl isothiocyanate administered subsequent to carcinogen exposure. Cancer Res. 41, 2991-2994.

49. Wattenberg, L. W. 1983. Inhibition of neoplasia by minor dietary constituents. Cancer Res. 43, 2448s-2551s.

50. Wiart, C. 2006. Family Caricaceae. In Medicinal Plants of the Asia-Pacific: Drugs for the Future? pp. 183-186, World Scientific Publishing Co. Pte. Ltd., Singapore.

51. Xie, T., M. Belinsky, Y. Xu, and A. K. Jaiswal. 1995. AREand TRE-mediated regulation of gene expression. J. Biol. Chem 270, 6894-6900.

52. Zhang, Y., P. Talalay, C. G. Cho, and G. H. Posner. 1992. A major inducer of anticarcinogenic protective enzymes from broccoli: isolation and elucidation of structure. Proc. Natl. Acad Sci. USA 15, 2399-2403.

53. Zhang, Y. and P. Talalay. 1994. Anticarcinogenic activities of organic isothiocyanates: chemistry and mechanisms. Cancer Res. 54, 1976-1981.

\section{초록 : 파파야씨 추출물 및 분획물의 항산화, $Q R$ 활성}

유미희 ${ }^{1} \cdot$ 이성규 ${ }^{1} \cdot$ 임효권 ${ }^{1,2} \cdot$ 채인경 $^{1} \cdot$ 김현정 $^{3} \cdot$ 이진호 ${ }^{4} \cdot$ 이인선 $^{1} \star$

( ${ }^{1}$ ㅖㅁ명대학교 식품가공학과, ${ }^{2}$ (재)대구테크노파크 바이오산업지원센터, ${ }^{3}$ 계명 대학교 TMR센터, ${ }^{4}$ 계명대학교 화학과)

본 연구에서는 파파야씨의 메탄올 추출몰과 분획물을 이용하여 항산화 활성 및 quinone reductase $(\mathrm{QR})$ 활성 을 측정하였다. 파파야씨의 추출물 및 분획물의 총 폴리페놀 함량은 $17.74 ~ 125.99 \mu \mathrm{g} / \mathrm{mg}$ 이며, 총 플라보노이드 함량은 1.60 32.69 $\mathrm{\mu g} / \mathrm{mg}$ 으로 나타났으며, ethyl acetate (EtOAc) 분획층의 총 폴리페놀 및 플라보노이드 함량이 다른 분획층과 비교했을 때 가장 높은 것으로 나타났다. a,a-Diphenyl- $\beta$-picrylhydrazyl (DPPH) radicals, 2,2'-azino-bis (3-ethylbenzthiazoline-6-sulfonic acid) (ABTS) and hydrogen peroxide를 이용하여 파파야씨 메탄올 추출 물 및 분획물의 항산화 활성을 조사한 결과, $\mathrm{EtOAc}$ 분획층에서 가장 높은 free radical 억제능을 보였다. 또한 $\mathrm{EtOAc}$ 분획층 $12.5 \sim 50 \mu \mathrm{g} / \mathrm{ml}$ 의 농도에서 $\mathrm{QR}$ 의 유도활성을 조사한 결과, $50 \mu \mathrm{gg} / \mathrm{ml}$ 의 농도에서 3.3배 정도의 $\mathrm{QR}$ 유도능을 보였다. 따라서 파파야씨의 EtOAc 분획층에 존재하는 물질들은 $\mathrm{QR}$ inducer 로써의 역할이 기대된다. 